\title{
Percutaneous endoscopic gastrostomy in porcines performed with standard medical instruments used in a general hospital routine ${ }^{1}$
}

Gastrostomia percutânea endoscópica em suínos realizada com instrumentos de uso rotineiro em hospital geral

\section{Luiz Roberto do Nascimento ${ }^{2}$, Caroline Moreira do Nascimento 3 , Fabiano Andrade Camargos ${ }^{3}$, Eduardo Carlos Grecco 4}

1. Laboratory of Technical Bases of Surgery of the Faculty of Medical Sciences of Pouso Alegre - Minas Gerais, Brazil.

2. PhD and Master in Surgical Technique and Experimental Surgery of Federal University of São Paulo (UNIFESP) Paulista School of Medicine (EPM). São Paulo, Brazil. Member of American Gastroenterological Association AGA.

3. Medical School Graduation Students of Alfenas Medical School (UNIFENAS). Alfenas-Minas Gerais, Brazil.

4. Head of Colonoscopy Unit of Santa Catarina Hospital, Gastroenterological Endoscopy Center. SãoPaulo, Brazil.

\begin{abstract}
PURPOSE: To perform a endoscopic gastrostomy by the introducer method with routine instruments used in a general hospital, without special instruments or special kits.

METHODS: This procedure was performed in pigs (Sus scrofa domesticus) under observation for seven days and then submitted to euthanasia.The technique was evaluated for macroscopic and histologic parameters. RESULTS: All animals had a good evolution without major complications. Some minor complications occurred like a rupture of Foley catheter balloon and subcutaneous space abscess.

CONCLUSION: The percutaneous gastrostomy with routine general hospital instruments is successful performed, is safe,cheap and must be performed by skilled endoscopists.
\end{abstract}

KEY WORDS: Surgery. Endoscopy. Stomach. Gastrostomy. Porcine.

\section{RESUMO}

OBJETIVO: Realizar uma gastrostomia endoscópica pelo método de punção, porém feita com instrumentos de uso rotineiro em um hospital geral, abolindo o uso de instrumentos especiais e de kits industrializados.

MÉTODOS: O procedimento foi realizado em suinos da raça Landrace (Sus scrofa domesticus ), que permaneceram em observação por sete dias, quando foram submetidos a eutanasia e avaliados por parâmetros macroscópicos ehistológicos.

RESULTADOS: Todos os animais tiveram boa evolução, não apresentando complicações importantes. Pequenas complicações, como ruptura do balão da sonda de Foley e abscesso subcutâneo ocorreram.

CONCLUSÃO: A gastrostomia percutânea endoscópica é um procedimento seguro, barato e perfeitamente realizável com materiais de uso rotineiro em um hospital geral, porém deve ser realizada por endoscopistas devidamente treinados.

DESCRITORES: Cirurgia. Endoscopia. Estômago. Gastrostomia. Porcos. 


\section{Introduction}

The endoscopic gastrostomy (PEG) was first idealized in1980 by Hashiba ${ }^{1,2}$, althougt the first medical publication in international literature was made later in same year by Gauderer and Ponsky ${ }^{3}$. The initial idea was to introduce an alternative to the laparotomy procedures creating a gastrocutaneous fistula with the purpose of feeding (nutrition) or palliative medication ${ }^{4,5}$. The technique has quickly become popular and became a standard procedure used throughout the world ${ }^{6,7}$ and many modifications have been introduced since then. There are many methods to perform the $\mathrm{PEG}^{8}$ :

1. The "Introducer Method" was first described by Hashiba1,2 and lately in international papers by Russel et al. in $1984^{8,9}$. It consisted of a feeding tube with a balloon on its edge which was directly introduced into the stomach under an endoscopic visibility ${ }^{8,9}$.

2. The "Pull Method" was the first described in international literature by Gauderer and Ponsky, and is the most popular and has gone through several modifications $^{3,8}$.

3. The "Push Method" also called the SacksVine method, actually it is the pull method modified, in which a wire guide once pushed outside the mouth is maintained pulled and then a feeding catheter is pushed over the guide wire ${ }^{8}$.

\section{Methods}

Ten male Landace pigs (Sus scrofa domesticus) weighing from 14100 to $14600 \mathrm{~g}$ were used. The experiment was performed at the Laboratory of Technical Bases of Surgery of the Faculty of Medical Sciences of Pouso Alegre. The animals remained without food for $24 \mathrm{~h}$ and without water for 12 hours prior to the experiment. After weighing the animals, preanesthetic medication using acepromazine ( $3 \mathrm{mg} /$ $\mathrm{kg})$ and atropine $(0.044 \mathrm{mg} / \mathrm{kg})$ was administered intramuscularly after which the animals were washed with soap and water. With the animal in dorsal decubitus, the lateral vein of the right ear was punctured using a 21-gauge needle which was then connected to physiological saline infused at a rate of $20 \mathrm{ml} / \mathrm{kg} / \mathrm{h}$. Intravenous thiopental (10 mg/kg) was used for sedation. The procedures below were followed:
1. Antisepsis of the abdominal wall with povidine.

2. Oral passage of the fibroscope until the stomach.

3. Distension of the stomach causing slight bulging of the abdominal wall (Figure 1).

4. Localization of the right point for puncture, by transillumination. This point is confirmed by pressing the abdominal wall with fingertip or a pointed object and observing at the gastric lumen through the endoscope.

5. A peridural anesthesia needle(PDA) $n^{\circ} 80$, is introduced percutaneously in the gastric lumen. A folded 2-0 mononylon thread is passed through its interior as to form a loop when the thread is pushed outside the end of the needle (Figure 2).

6. Parallel to this puncture and $2.0 \mathrm{~cm}$ from it, a 80-10 needle, like those used for spinal anesthesia (SA) is introduced percutaneously.

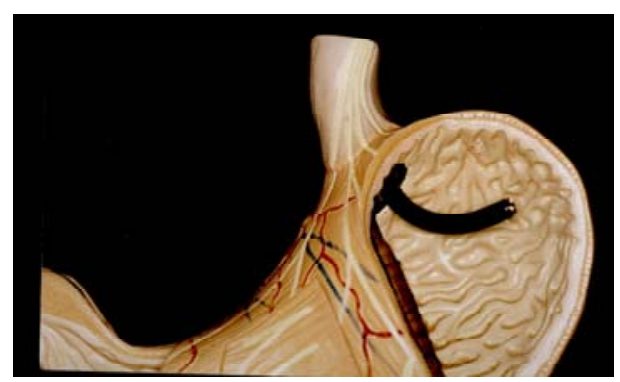

FIGURE 1 - Shows stomach been distending.

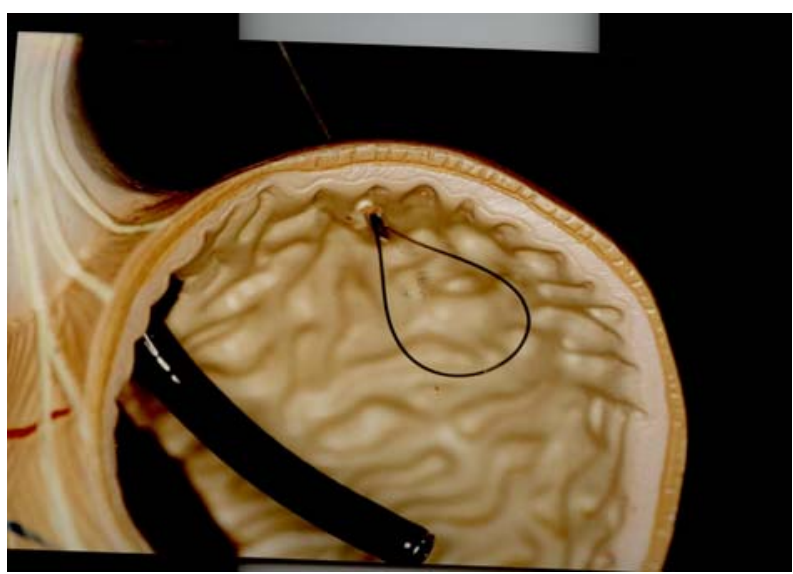

FIGURE 2 - Folded mononylon passed through inside lumen of peridural needle $\mathrm{N}^{\mathrm{o}} 80$. 
7. The SA needle is passed through the loop (Figure 3).

8. A 2-0 mononylon thread is passed inside the SA needle (Figure 4).

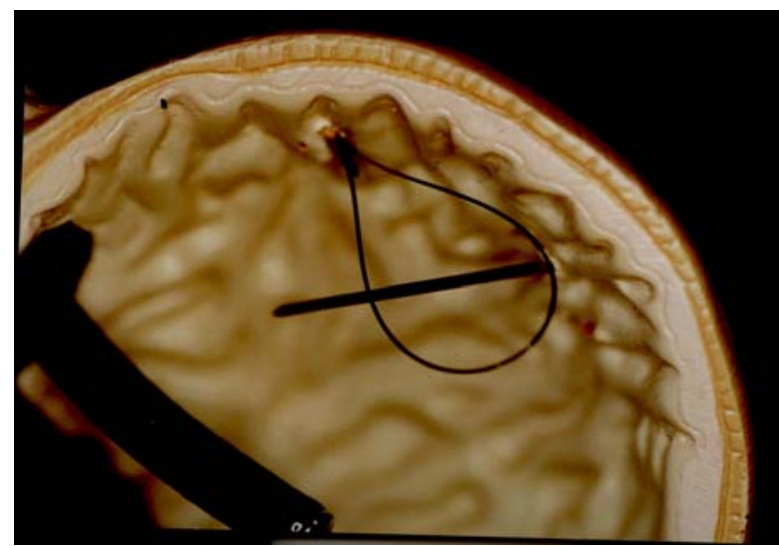

FIGURE 3 - The parallel puncture of spinal needle is done and passed through the loop before forming.

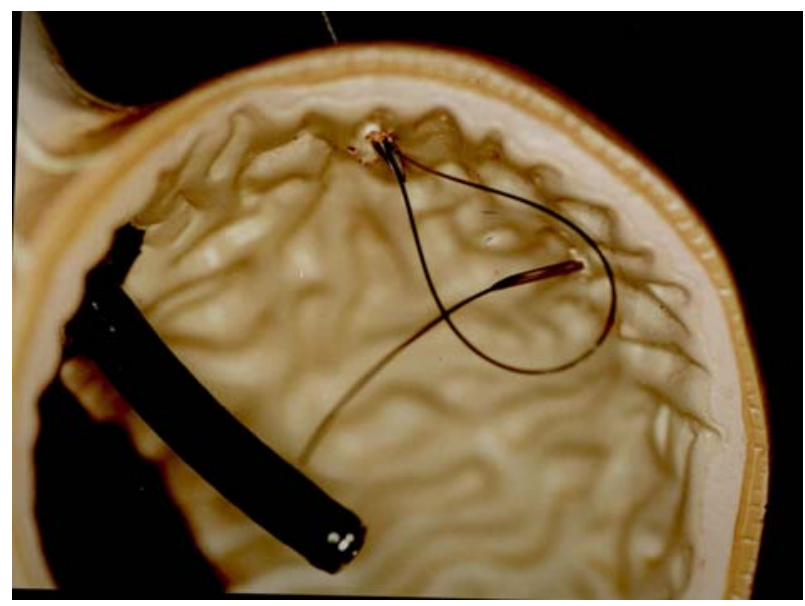

FIGURE 4 - Another mononylon thread is passed inside the AS needle through inside lumen, thus this thread is holded.

9. The folded thread is pulled into PDA needle and emerging from its upper end, when the thresd of SA is exteriorized. This thread is anchored to the abdominal wall forming a U stitch (Figure 5).

10. The procedure is repeated for another stitch parallel to and $3 \mathrm{~cm}$ from the first, so as to form two U stitches anchoring the gastric wall to the parietal peritoneum between which the trocar will pass (Figures 6A and 6B).

11. A one $\mathrm{cm}$ incision between the stitches is made in the skin. An urological trocar is introduced

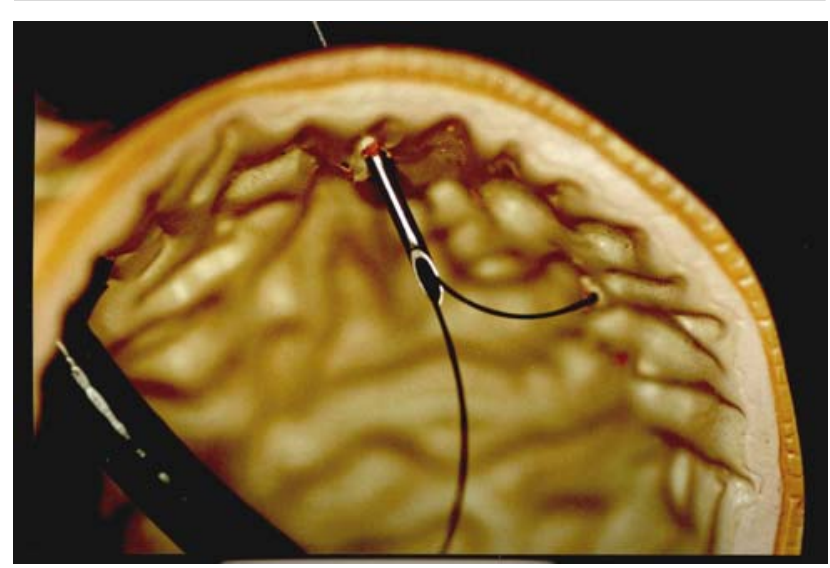

FIGURE 5 - Schematic view: folded thread is pulled into PDA with SA thread.

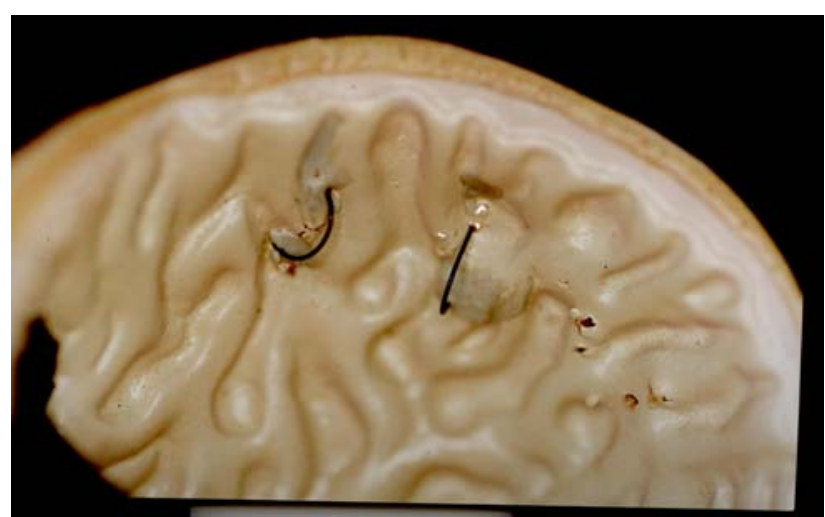

FIGURE 6A - Schematic gastric view: two paralell U stiches anchoring the gastric wall to the parietal peritoneum.

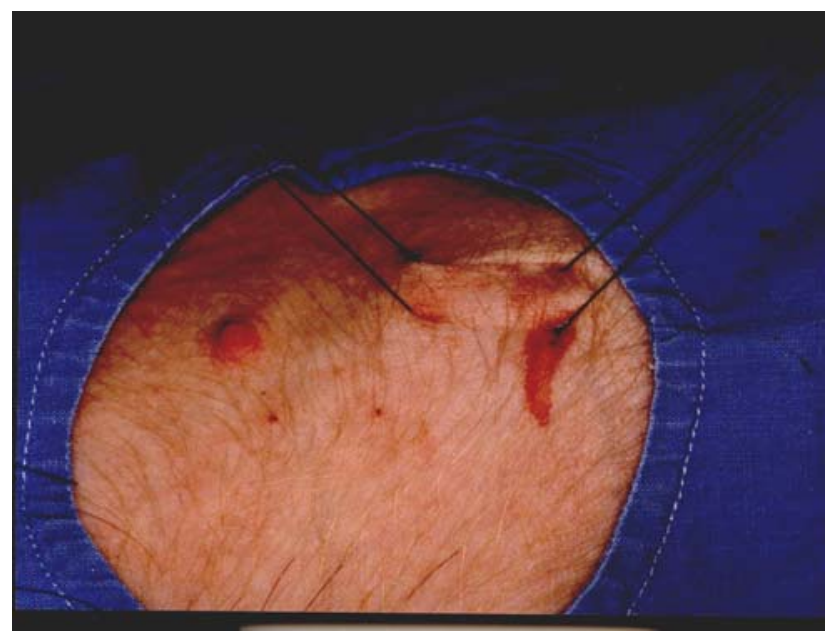

FIGURE 6B - Surgery external view: two parallel U stiches anchoring the gastric wall to the parietal peritoneum.

up to the gastric lumen visualized through the endoscope (Figures 7, 8 and 9).

12. $A n^{\circ} 18$ Foley catheter is passed through the 


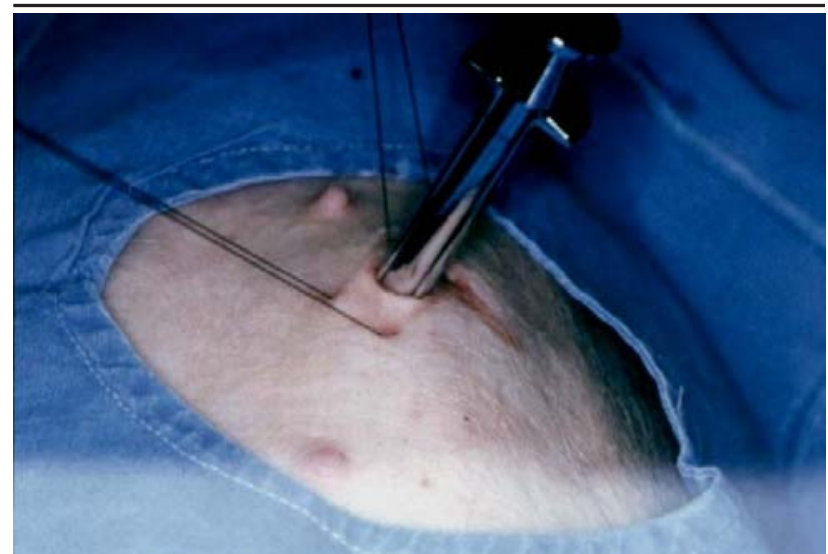

FIGURE 7 - Surgery view of urological trocar been introduced on the skin until the gastric lumem.

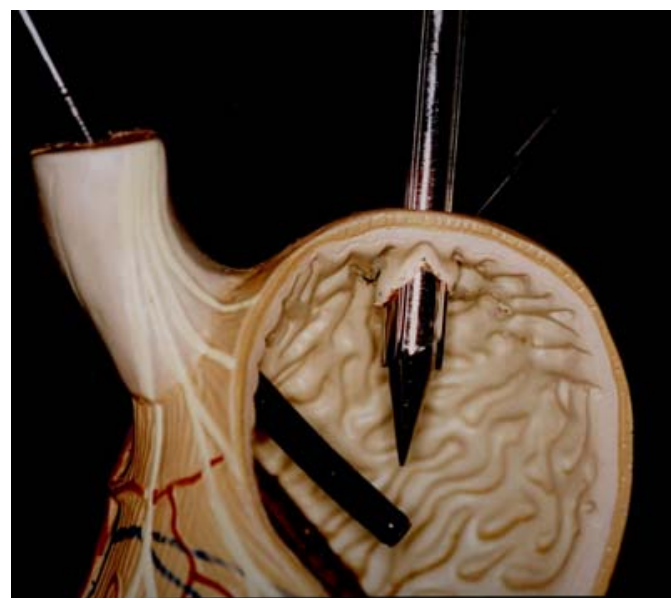

FIGURE 8 - Schematic view of urological trocar been introduced on the gastric lumem.

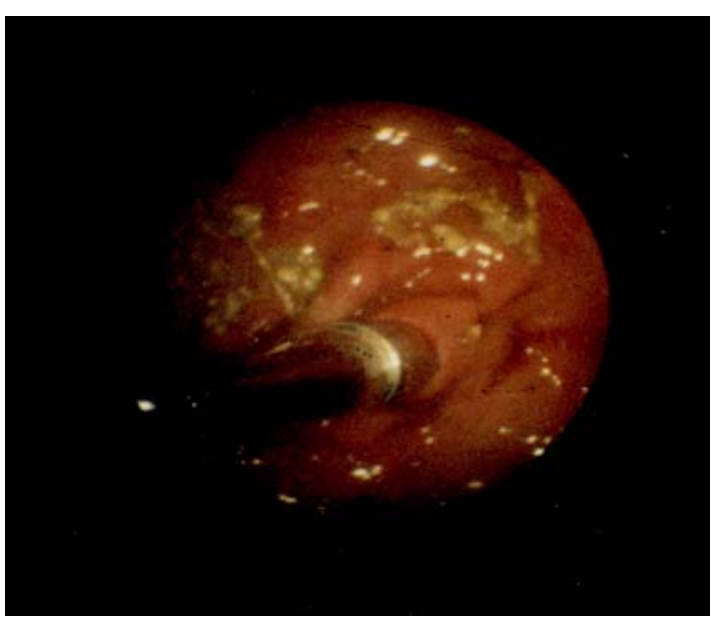

FIGURE 9 - Endoscopic view of urological trocar been introduced on the gastric lumem.

lumen of the trocar. Its balloon is filled with distilled water and the trocar is removed (Figure 10).

13. The catheter is pulled opposite to the abdominal wall and is fixed at the skin with 2-0 mononylon (Figures 11 and 12).

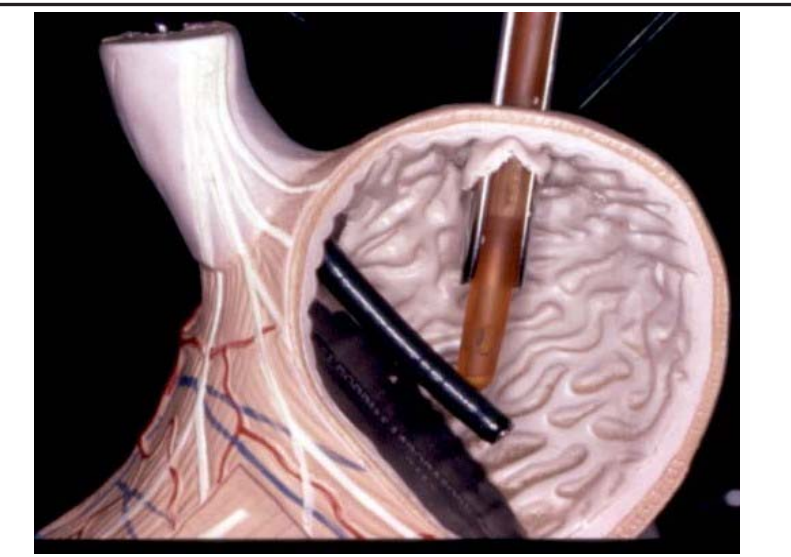

FIGURE 10 - Foley catheter is passed through the lumem of the urological trocar.

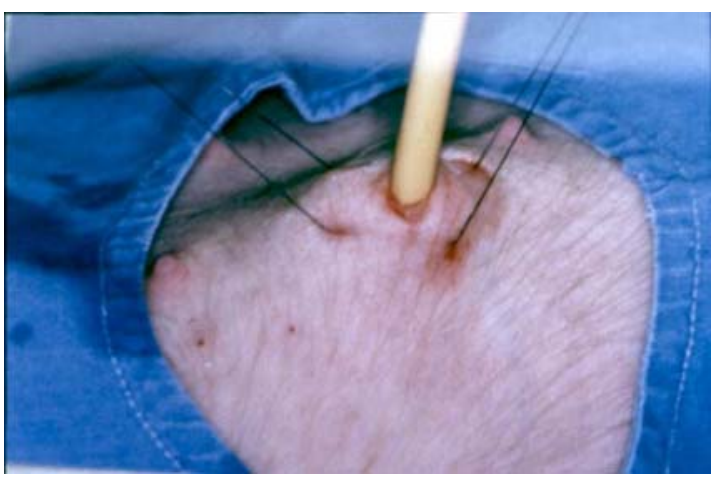

FIGURE 11 - Schematic view of Foley catheter pulled opposite to the abdominal wall.

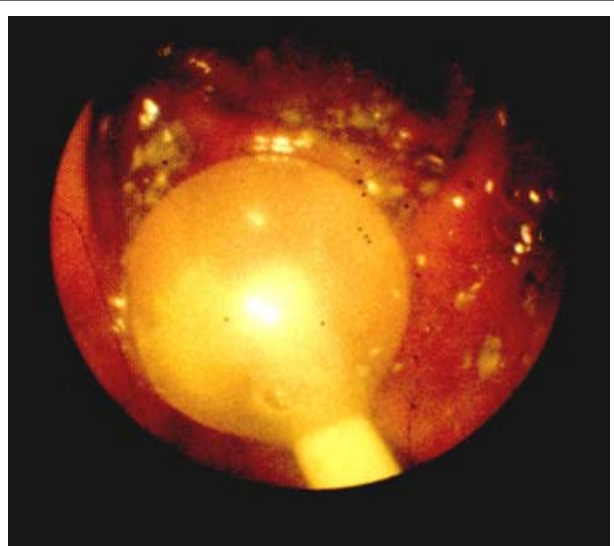

FIGURE 12 - Endoscopic view of Foley catheter pulled opposite abdominal wall.

14. Four $\mathrm{cm}$ above the skin the catheter is occluded using 2-0 mononylon thread and a double knot, being then sectioned (Figure 13).

15. This catheterstump isleftinasubcutaneoustunnel.

16. The skin is sutured using 2-0 mononylon (Figure14).

On recovery from the anesthesia the animals were 
fed after $12 \mathrm{~h}$ and remained for 7 days under observation after which they were submitted to euthanasia with endovenous potassium chloride. A midline laparotomy was performed for inspection of the cavity and the site of gastrostomy, externally (Figure 15).

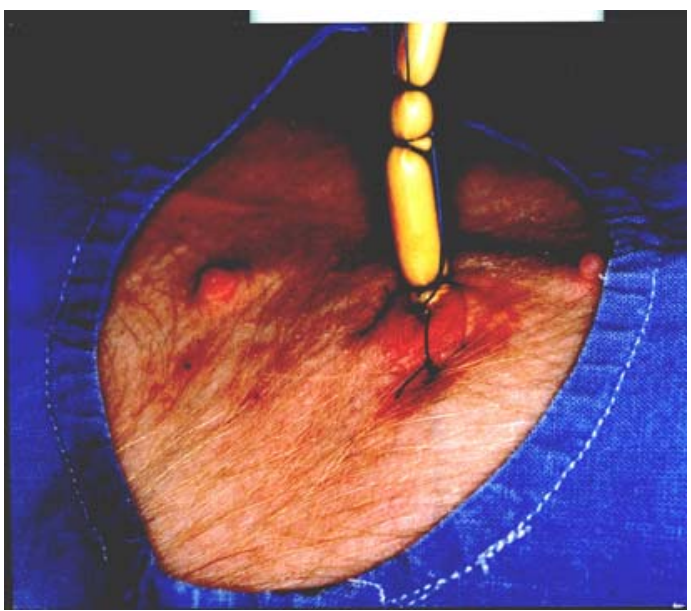

FIGURE 13 - Foley catheter is occluded four $\mathrm{cm}$ above the skin.

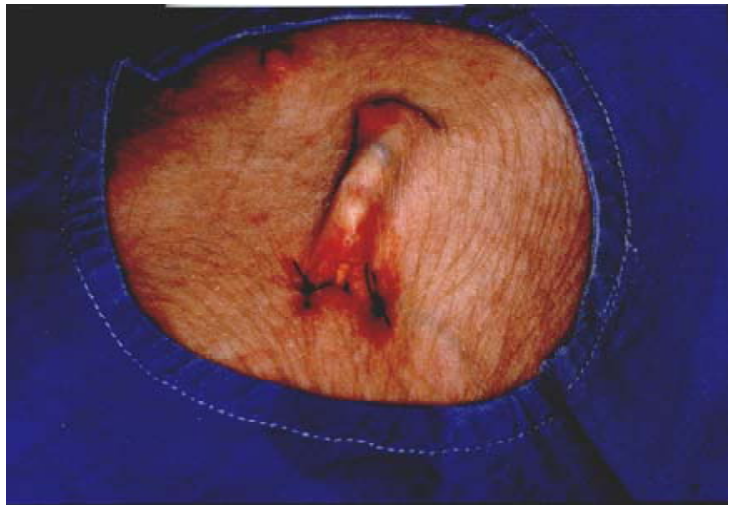

FIGURE 14 - Subcutaneus tunnel with the stump of Foley catheter and sutured skin.

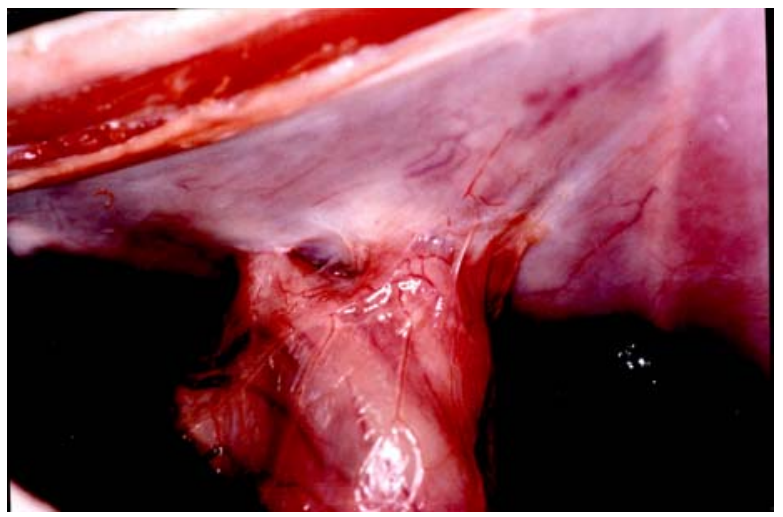

FIGURE 15 - Laparotomy shows the gastrostomy externally.
The stomach was opened for internal inspection of the gastrostomy.

The specimen was removed, comprising all planes in a radius of $4 \mathrm{~cm}$ around the site of puncture (Figure 16).

The site of adherence of the gastric wall and parietal peritoneum was submitted to histopathological examination.

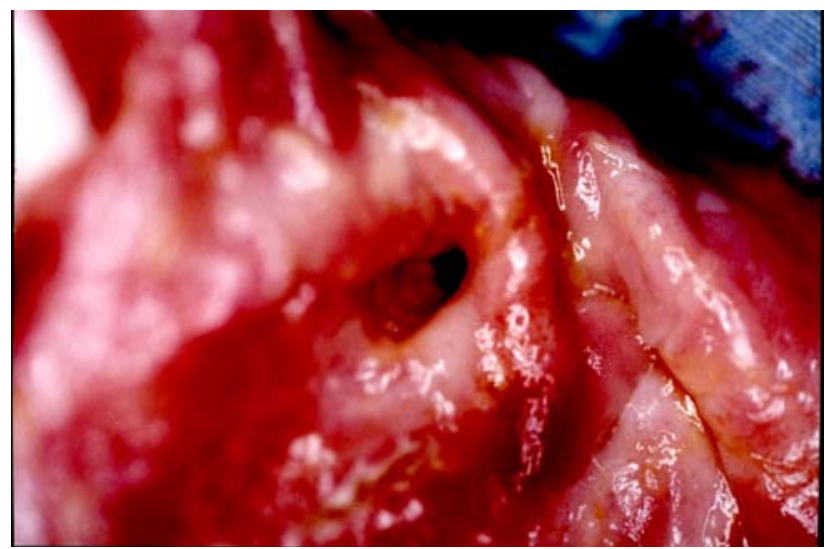

FIGURE 16 - Gastrotomy specimen is removed for histopatological study.

\section{Results}

All the studied animals had a good evolution in the postoperative period, not presenting major complications. In one animal there was a small abscess in the subcutaneous space where the catheter remained, but without signs of food extravasation. In two animals, the Foley catheter balloom was ruptured, also without presenting signs of food extravasation to the subcutenous tissue (Figure 17).

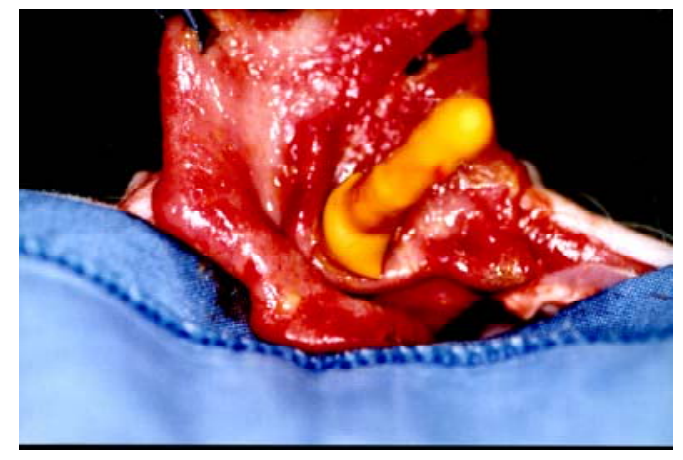

FIGURE 17 - Surgery view of Foley baloom ruptured. 
In all of them, there was a perfect adherence of the gastric wall to the parietal peritoneum,both macroscopically and microscopically (Figure 18).

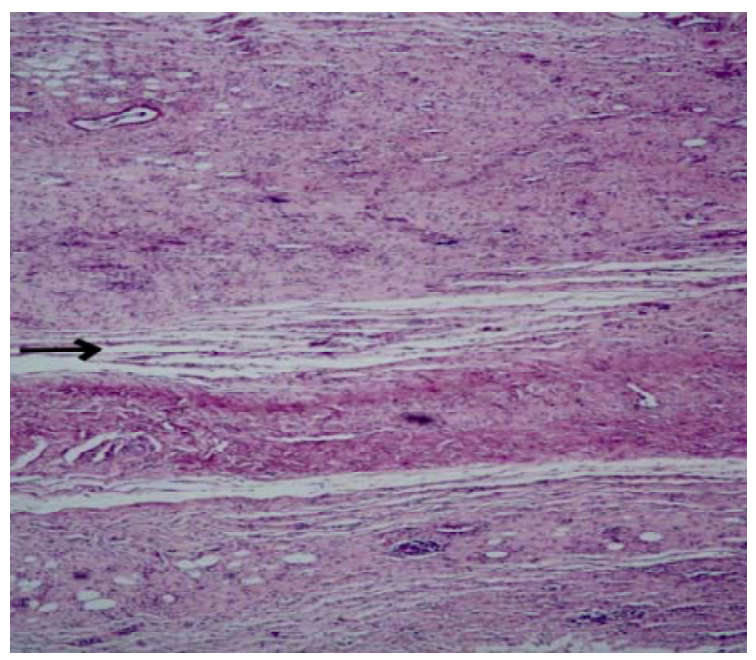

FIGURE 18 - Histological view shows perfect adherence of the parietal peritoneum (arrow).

\section{Discussion}

Swines are successfully used as teaching models for diagnostic endoscopy and therapy in several teaching centers because of their anatomical similarity with the human stomach10. To perform an endoscopic percutaneous gastrostomy, a skilled endoscopist is needed because this procedure is subject to complications of the method8. The objective of the PEG technique was to provide a secure alternative for the open method, being the laparotomy eliminated3,5. From the first results, PEG showed to be as safe as the open gastrostomy and it was quickly and easily performed and the patient is earlier discharged from the hospital (11). Reviews on several series of PEG revealed that insertion of catheter was successful in $98 \%$ of the cases with a mortality rate of $0.7 \%$. Minor complications occurred in 6 to $7 \%$ of the cases and major complications around 3\%11,12. The introducer technique, when compared to the Push or Pull techniques, has several advantages including a single pass of the endoscope, the capacity to insert the gastric tube even with a partial obstruction of the esophagus and the use of the Seldinger technique which is very familiar to us8,13. The additional advantage is to avoid oropharyngeal and esophageal lesion and the absence of contamination, which theoretically leads to low rates of infection in the periostoma. The implantation of metastasis in the wall is added8,13. Dietel et al.14, in a comparative study found that the introducer method is faster and associated with a lower rate of infection than the other methods14. In case of obstruction or spontaneous extubation of the catheter it is easily placed by the introducer technique and a second gastroscopy to remove the catheter8 is no longer needed.The major disadvantage of this technique is the use of an inflated balloon which is less secure and associated with earlier displacements of the catheter15. This complication can be avoided by anchoring stitches between the stomach and the gastric wall8 as it was described in this method. The absence of dehiscence in series published by Hashiba2 is due to the anchoring with total four $\mathrm{U}$ stitches. In this our study we perfomed two anchoring stitches because it is perfectly adequate to maintain appositioning of the stomach and parietal peritoneum. Regarding the performance of the stitches, Hashiba2 used a special needle properly executed for this purpose. Routine needles were used in anesthesia, being perfectly possible to perform these stitches with those needles, thus accessible to any endoscopist. Hashiba2 used a special trocar that remains attached to the catheter when the procedure is accomplished. The advantage of the suprapubic urologic trocar is the possibility of withdrawing it from the catheter right after the pass of the same through the gastric light.

\section{Conclusion}

Percutaneous endoscopic gastrostomy must be performed by skilledendoscopists. How itwas described is successful performed, safeand with low costs.

\section{References}

01. Hashiba K- Técnica de abertura de gastrostomia sob controle e manipulação endoscópica. Rev Paul Med 1980;95:37-8.

02. Hashiba K. Abertura de gastrostomia percutânea, endoscópica ,sem laparotomia [Tese - Livre Docência]. Universidade de São Paulo; 1982.

03. Gauderer MWL, Ponsky JL, Izant R.JJr. Gastrotomy without laparotomy: a percutaneous endoscopic technique. J Pediatr Surg 1980;15:872-5.

04. Ponsky JL, Gauderer MWL. Percutaneus endoscopic gastrostomy: a non operative technique for feeding gastrostomy. Gastrointest Endosc 1981;27:9-11.

05. Greff M. Guidelines of french society of digestive endoscopy(SFED): endoscopic gastrotomy. Endoscopy 1999;31(2):207-8. 
06. Amann W, Mischinger HJ, Berger A. Percutaneus endoscopic gastrostomy (PEG): 8 years of clinical experience in 232 patients. Surg Endosc 1997;11:741-4.

07. Ponsky Jl Gauderer MWL, Stellato TA, Aszodi A. Percutaneus approaches to enteral alimentation. Am J Surg 1985;20:1006-9.

08. Safadi BY, MaarksJM, PonskyJL. Percutaneous endoscopic gastrotomy: an update. Endoscopy 1998;30(9):781-9.

09. Russel TR, Brotman M, Norris F. Percutaneus gastrostomy: a new simplified and cost-efective technique. Am J Surg 1984;148:132-7.

10. Freys SM, Heimbucher J, Mfuchs KH. Teaching upper gastrointestinal endoscopy: the pig stomach. Endoscopy
1995;27:73-6.

11. Miller RE, Krumer BA, Kotler DP, Tiszenkel HI. Percutaneus endoscopic gastrostomy: procedure of choice. Ann Surg 1986;217:168-74.

12. Sangster W, Cuddington GD, Bachulis Bl. Percutaneus endoscopic gastrostomy. Am J Surg 1988;155:677-9.

13. Marks JM, Ponsky JL. Acess routes for enteral nutrition. Gastroenterology 1995;3:130-9.

14. Dietel M, Bendago M, Spratt EH, Burul CJ. Percutaneous endoscopic gastrostomy by "pull” and “introducer”methods. Can J Surg 1991;31:552-3.

15. PetersenTI, Kruse A. Complications of percutaneous endoscopic gastrostomy. Eur J Surg 1997;163:351-6.

\section{Correspondence: \\ Luiz Roberto do Nascimento \\ Rua. Expedito da Silva Maia, 75 \\ 37550-000 Pouso Alegre-MG Brazil \\ Tel: (55 35)3422-9924 / 34222531 \\ Tel/Fax: (5535)3423-6405/34225727 \\ lrnasci@uol.com.br \\ luizrnascimento@tcnet.com.br}

Received: May 11, 2004

Review: June 15, 2004

Accepted: July 14, 2004

Conflict of interest: none

Financial source: none

\section{How to cite this article:}

Nascimento LR, Nascimento CM, Camargos FA, Grecco EC. Percutaneous endoscopic gastrostomy in porcines performed with standard medical instruments used in a general hospital routine. Acta Cir Bras [serial online] 2004 Sept-Oct;19(5). Available from URL: http://www.scielo.br/acb [also in CD-ROM].

*Color figures available in www.scielo.br/acb 